\title{
The cost of lithium is unlikely to upend the price of Li-ion storage systems
}

\author{
Rebecca E. Ciez $\%$ J.F. Whitacre* + t, \\ $\dagger$ Department of Engineering \& Public Policy, $\$$ Department of Materials Science and \\ Engineering, Carnegie Mellon University, 5000 Forbes Avenue, Pittsburgh, Pennsylvania 15213, \\ United States \\ * Corresponding Author, Tel: (412) 268-5548; Fax: 412-268-3757; E-mail: \\ whitacre@andrew.cmu.edu
}

\begin{abstract}
As lithium ion batteries become more common in electric vehicles and other storage applications, the cost of these batteries will be highly dependent on its namesake material. However, examining the constituent materials of these devices shows that lithium is a relatively small contributor to both the battery mass and manufacturing cost. The use of more expensive lithium precursor materials results in less than $1 \%$ increases in the cost of lithium ion cells considered. Similarly, larger fluctuations in the global lithium price (from $\$ 0$ to $\$ 25 / \mathrm{kg}$ from a baseline of $\$ 7.50$ per $\mathrm{kg}$ of $\mathrm{Li}_{2} \mathrm{CO}_{3}$ ) do not change the cost of lithium ion cells by more than $10 \%$. While this small cost increase will not have a substantial impact on consumers, it could affect the manufacturers of these lithium ion cells, who already operate with small profit margins.
\end{abstract}

\section{Introduction}

Lithium ion battery powered electric vehicles are a reality, and with this comes much public and academic speculation concerning the importance of lithium availability and market price. Despite substantial cost reductions in recent years (59-70\% per kWh between 2007 and 2014),[1] lithium ion batteries are still significantly more expensive than the Department of Energy target of $\$ 125 / \mathrm{kWh}$ by 2022.[2] Precursor materials are a dominant contributor to battery mass and cost, and it is suggested in some corners that lithium prices will prove to be a crucial factor in the cost of battery storage. Some investors believe that inexpensive lithium is one key to 
reducing device and system costs, while others believe that increased demand will draw geopolitical and economic concerns about access to supply on par with current concerns about oil. $[3,4]$ In both cases, it is assumed that extreme fluctuations in the lithium market could have a dramatic effect on the manufacturing cost of lithium ion batteries, and the corporate value proposition of these devices.[5] Furthermore, both lithium shortages and price instability are frequently used as justifications for research on alternate cation electrochemical energy storage systems such as sodium, magnesium, and potassium based systems. Here we show that even substantial increases in lithium costs will have relatively small $(<10 \%)$ increases in total manufacturing costs per $\mathrm{kWh}$ at the cell level, and comment on the impact this change in manufacturing cost could impact automotive lithium ion battery manufacturers.

\section{Methods}

We select two cell designs and two lithium ion battery chemistries, both based on Argonne National Lab's BatPaC model (specifically version 3B, released in May 2015).[6] They represent two different types of cells typically found on the market. Batteries with lithium manganese oxide spinel $\left(\mathrm{LiMn}_{2} \mathrm{O}_{4}\right)$ and lithium nickel cobalt aluminum oxide $(\mathrm{LiNiCoAlO})$ cathodes are currently used in several prominent PHEV and BEV models, so we use these cathode chemistries. In all cases the anode material is graphitic carbon. "High specific power" cells are used for applications where higher power per unit energy is needed, such as hybrid (HEV) and plug-in hybrid battery packs (PHEV), whereas "high specific energy" cells are used for all-electric battery electric vehicles (BEV). The high specific power cells are capable of faster charging and discharging, and have thinner electrodes and a higher mass fraction of current collector and separator material per cell. The high specific energy cells have thicker electrodes and lower mass fraction of separators and current collectors. Some of the key cell parameters 
from the BatPaC model for both cell formats and chemistries are listed in Table 1. From these cell models, we are able to construct a bill of materials and break down the costs of the cells, which is shown in Figure 1.

\begin{tabular}{|l|l|c|c|c|c|}
\hline \multirow{2}{*}{$\begin{array}{l}\text { Cathode } \\
\text { Chemistry }\end{array}$} & Cell Format & $\begin{array}{l}\text { Number } \\
\text { of Bicell }\end{array}$ & $\begin{array}{l}\text { Cell } \\
\text { Capacity }\end{array}$ & \multicolumn{2}{|l|}{$\begin{array}{l}\text { Electrode Material } \\
\text { (kg/kWh) }\end{array}$} \\
\cline { 5 - 7 } & Layers & (Ah) & Positive & Negative \\
\hline $\mathrm{LiMn}_{2} \mathrm{O}_{4}$ & High Specific Power & 47 & 11.4 & 1.97 & 1.16 \\
\cline { 2 - 6 } & High Specific Energy & 17 & 46.1 & 1.76 & 1.15 \\
\hline $\mathrm{LiNiCoAlO}_{2}$ & High Specific Power & 25 & 10.6 & 2.94 & 1.04 \\
\cline { 2 - 6 } & High Specific Energy & 19 & 42.5 & 2.94 & 1.02 \\
\hline
\end{tabular}

Table 1: Key cell parameters from BatPaC model

From this bill of materials, we calculate the stoichometrically balanced combinations of precursor materials used to make both the cell cathode and electrolyte (1.2 $\left.\mathrm{M} \mathrm{LiPF}_{6}\right)$, the only cell elements containing lithium. The lithium compounds, cathode precursor materials, and electrolyte precursor materials considered are listed in Table 2. We use lithium carbonate $\left(\mathrm{Li}_{2} \mathrm{CO}_{3}\right)$ as the baseline estimate and compare it to combinations using lithium hydroxide $(\mathrm{LiOH})$, which is approximately $15 \%$ more expensive per mole of lithium content. $[7,8]$

\begin{tabular}{|c|c|c|c|}
\hline \multirow{2}{*}{$\begin{array}{l}\text { Lithium Precursor } \\
\text { Materials }\end{array}$} & \multicolumn{2}{|c|}{ Cathode Precursor Materials } & \multirow{2}{*}{$\begin{array}{l}\text { Electrolyte } \\
\text { Precursor Materials }\end{array}$} \\
\hline & $\mathrm{LiMn}_{2} \mathrm{O}_{4}$ & $\mathrm{LiNiCoAlO}_{2}$ & \\
\hline $\mathrm{Li}_{2} \mathrm{CO}_{3}, \mathrm{LiOH}$ & $\begin{array}{l}\mathrm{Mn}_{3} \mathrm{O}_{4}, \mathrm{MnCO}_{3}, \\
\mathrm{MnO}_{2}\end{array}$ & $\begin{array}{l}\mathrm{NiSO}_{4}, \mathrm{Ni}\left(\mathrm{NO}_{3}\right)_{2}, \\
\mathrm{CoSO}_{4}, \mathrm{Co}\left(\mathrm{NO}_{3}\right)_{2}, \\
\mathrm{Al}(\mathrm{OH})_{3}\end{array}$ & $\mathrm{HF}, \mathrm{PF}_{5}$ \\
\hline
\end{tabular}

Table 2: Precursor materials considered

We also perform a sensitivity analysis to determine the influence of large fluctuations in the lithium carbonate price. Here we specify a lower cost bound of $\$ 0$ per $\mathrm{kg}$, and an upper bound of $\$ 25 / \mathrm{kg}$ from a baseline of $\$ 7.50 / \mathrm{kg}$ (which is a reasonable approximation of the recent lithium price).[9-11]This upper bound is consistent with the highest estimate of the cost of extracting lithium from seawater, the world's largest lithium source, which could be utilized if justified by global demand. [12] 


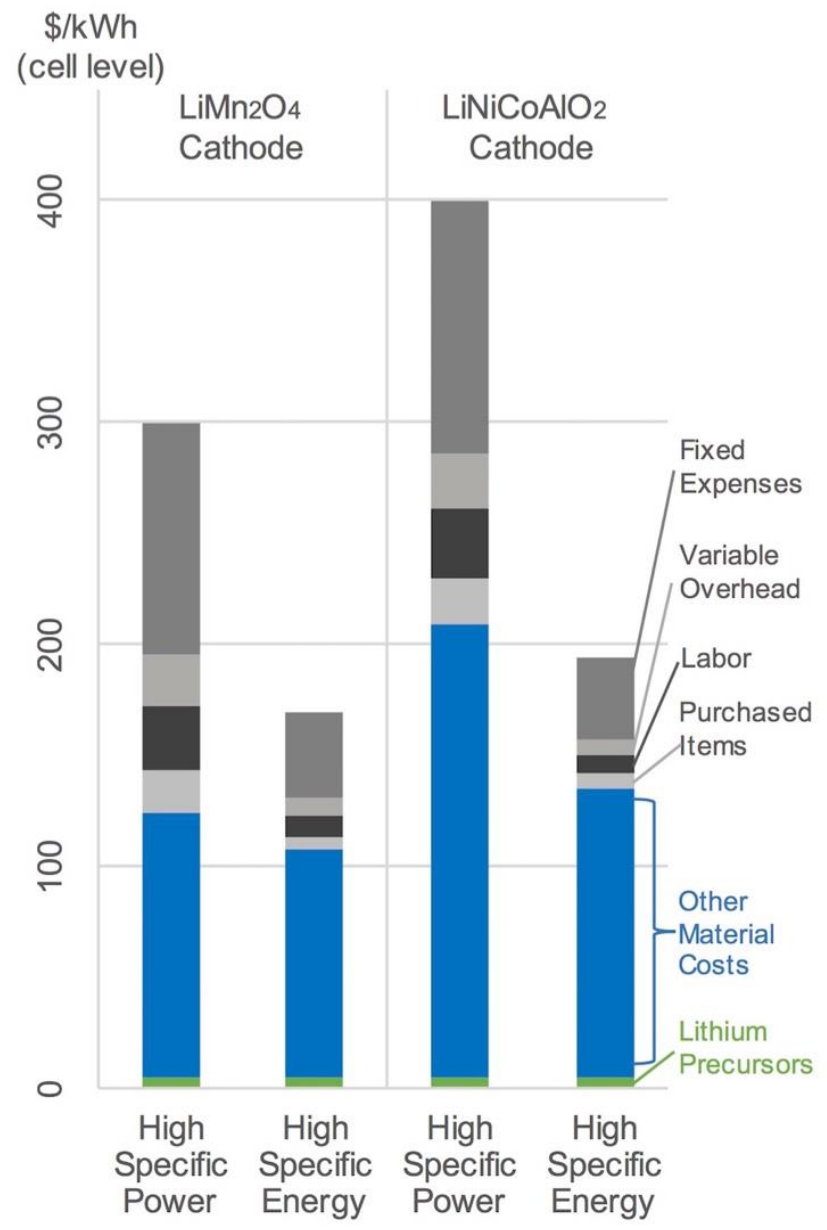

Figure 1: Per kWh cell-level costs for lithium manganese oxide spinel $\left(\mathrm{LiMn}_{2} \mathrm{O}_{4}\right)$ and lithium nickel cobalt aluminum oxide $\left(\mathrm{LiNiCoAlO}_{2}\right)$ batteries for high specific power and high specific energy cells. High specific power cells are typically used in PHEVs, while high specific energy cells are used in BEVs with larger battery packs

\section{Results \& Discussion}

Our analysis shows that the use of lithium hydroxide, the slightly more expensive lithium compound, is unlikely to have a significant impact on the cost of batteries. For example, Table 3 shows the cost increase associated with making cathode materials with $\mathrm{LiOH},[13]$ instead of the 
standard lithium carbonate material . Using the significantly costlier $\mathrm{LiOH}$ results in a less than $1 \%$ increase in the overall cost of the cells in $\$ / \mathrm{kWh}$.

\begin{tabular}{|c|c|c|c|}
\hline $\begin{array}{l}\text { Cathode } \\
\text { Chemistry }\end{array}$ & Cell Format & \multicolumn{2}{|c|}{$\begin{array}{l}\text { Cost and percentage increase when } \\
\text { using } \mathrm{LiOH} \text { compared to } \mathrm{Li}_{2} \mathrm{CO}_{3}\end{array}$} \\
\hline \multirow[t]{2}{*}{$\mathrm{LiMn}_{2} \mathrm{O}_{4}$} & High Specific Power & $\$ 0.84 / \mathrm{kWh}$ & $0.3 \%$ \\
\hline & High Specific Energy & $\$ 0.84 / \mathrm{kWh}$ & $0.51 \%$ \\
\hline \multirow[t]{2}{*}{$\mathrm{LiNiCoAlO}_{2}$} & High Specific Power & $\$ 0.72 / \mathrm{kWh}$ & $0.18 \%$ \\
\hline & High Specific Energy & $\$ 0.71 / \mathrm{kWh}$ & $0.35 \%$ \\
\hline
\end{tabular}

Table 3: per kWh additional costs associated with using lithium hydroxide $(\mathrm{LiOH})$

The global lithium price is subject to market demand, but despite the projected increase in demand for lithium, long-term lithium production is expected to meet this demand.[14] The analysis of the market fluctuations in the lithium carbonate price also shows relatively small impacts on the cost of lithium ion cells. Figure 2 shows that even if $\mathrm{Li}_{2} \mathrm{CO}_{3}$ were to be completely free, the reduction in cost per $\mathrm{kWh}$ is relatively small, $3 \%$ or less for all four batteries considered. As such, even if the global lithium market slows substantially, which is possible given the recent global downturn in commodities in general,[15] the impact on cell and pack level cost is small. Similarly, lithium price increases of more than $300 \%$ - from $\$ 7.50 / \mathrm{kg}$ to $\$ 25 / \mathrm{kg}$ - would not lead to commensurate increases in battery costs; the maximum increase in the cost per $\mathrm{kWh}$ for the four batteries considered is less than $10 \%$. To have even a $15 \%$ increase in cell costs, lithium prices would have to be much higher-between $\$ 36$ and $\$ 87 / \mathrm{kg}$ - depending on the specific cell chemistry and format. These prices are unsustainably high, and would trigger other lithium producers to enter the market, increasing supply and reducing prices to the ocean removal cost.

Although in absolute terms these cost fluctuations seem relatively small, they can be significant to lithium ion battery manufacturers, who operate under very narrow profit margins, and are currently engaged in a "race to the bottom" to truly enable the burgeoning large format 
energy storage market.[16-18] LG Chem operated at a $0.7 \%$ loss in 2015, and profit projections are 5\% or less for the next 2 years.[17] Panasonic has similar trends, with their lithium ion division suffering significant losses as recently as 2012. Specific data on the profitability of their lithium ion battery operation is limited, but they reported $5.8 \%$ profits in the second quarter of 2013,[18] and the larger Automotive \& Industrial Systems division, where battery manufacturing accounts for approximately $30 \%$ of operations, posted profits of less than $4 \%$ in both 2014 and 2015.[19] Given these narrow profitability margins, we can expect additional concerns about securing the rights to lithium resources, but securing these rights alone will not significantly reduce the cost of cells to consumers. In the long-term, additional lithium resources can be captured to provide the materials necessary to continue expanding production volumes of lithium ion batteries.

\section{Conclusions}

This uncertainty in lithium pricing suggests that strategic sourcing of this important material will likely not be a key factor in the long term quest to reduce the production costs of lithium ion batteries, but increases in lithium prices will not be a driver of significant cost increases either. Using more expensive $\mathrm{LiOH}$ precursor materials leads to a less than $1 \%$ increase in the cell cost, and $300 \%$ increases in the global lithium price increase the cost of these cells by less than $10 \%$. In the worst case producers will either see their thin profit margins eroded or will have to pass on these small increases to the customer. While there are many other reasons to explore other battery chemistries, justifying research on other battery chemistries in the name of avoiding the economic issues associated with lithium is misguided; Lithium is plentiful, has little impact on battery cell and pack costs, and is here to stay. 


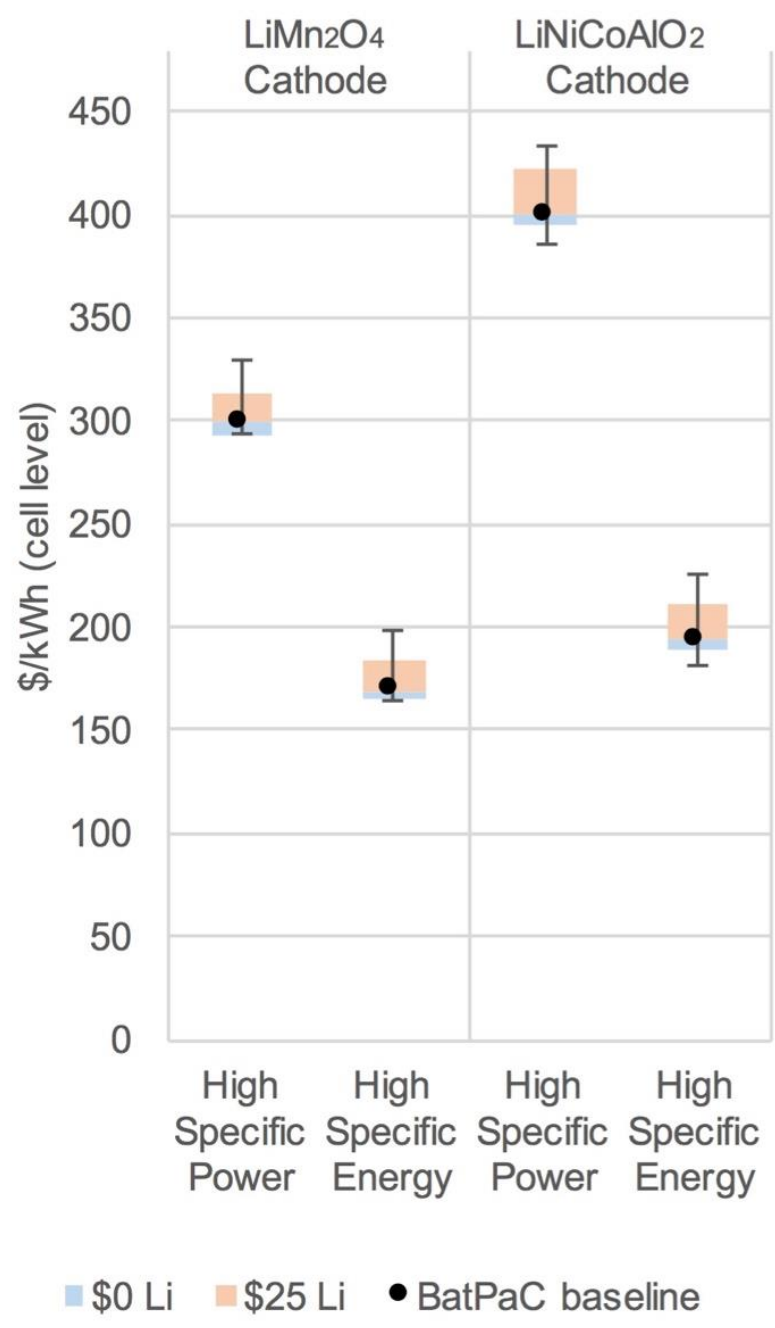

Figure 2: Cell costs with variations in lithium prices, when compared to the $\mathrm{BatPaC}$ baseline estimate and price uncertainty for positive electrode and electrolyte materials.

\section{Acknowledgements}

This material is based upon work supported by the National Science Foundation Graduate Research Fellowship Program under Grant No. 1252522. Any opinions, findings, and conclusions or recommendations expressed in this material are those of the author(s) and do not necessarily reflect the views of the National Science Foundation. Additional funding for this 
research was provided by Carnegie Mellon University, Aquion Energy, and the Bushnell

Fellowship in Engineering.

\section{References}

[1] B. Nykvist, M. Nilsson, Rapidly falling costs of battery packs for electric vehicles, Nature Climate Change. 5 (2015) 329-332. doi:10.1038/nclimate2564.

[2] Vehicle Technologies Office: Batteries, Energy.Gov. (n.d.). http://energy.gov/eere/vehicles/vehicle-technologies-office-batteries (accessed December 30, 2015).

[3] M. DeBord, This Tesla analyst has an incredibly out-there thesis about the company's future, Business Insider. (2016). http://www.businessinsider.com/tesla-bull-tripchowdhry-bets-on-fall-in-lithium-prices-2016-1 (accessed February 4, 2016).

[4] V. Mansharamani, Could lithium become the new oil? (2015). http://www.pbs.org/newshour/making-sense/lithium-become-new-oil/ (accessed February 4, 2016).

[5] Tesla's Lithium Supply Constraints Might Hamper Its Growth, Forbes Investing. (n.d.). http://www.forbes.com/sites/greatspeculations/2015/03/16/teslas-lithium-supplyconstraints-might-hamper-its-growth/ (accessed January 27, 2016).

[6] P. Nelson, K. Gallagher, I. Bloom, BatPaC, Argonne National Laboratory. (n.d.). http://www.cse.anl.gov/batpac/download.php.

[7] citychemical.com, n.d. http://www.citychemical.com (accessed January 28, 2016).

[8] sigmaaldrich.com, n.d. http://www.sigmaaldrich.com (accessed January 28, 2016).

[9] F. Els, CHARTS: Giant gap between future lithium supply, demand, Mining.com. (2014). http://www.mining.com/charts-chasm-between-future-lithium-supply-demand28137/ (accessed January 26, 2016).

[10] P.A. Nelson, K.G. Gallagher, I. Bloom, D.W. Dees, Modeling the Performance and Cost of Lithium-Ion Batteries for Electric-Drive Vehicles, 2012.

[11] T.D. Kelly, G.R. Matos, C.A. DiFrancesco, K.E. Porter, Historical Statistics for Mineral and Mineral Commodities in the United States, Minerals.Usgs.Gov. (n.d.).

[12] R. Martin, Quest to Mine Seawater for Lithium Advances, MIT Technology Review. (2015). https://www.technologyreview.com/s/538036/quest-to-mine-seawater-forlithium-advances/ (accessed February 5, 2016).

[13] M. Anderman, The Plug-In Hybrid and Electric Vehicle Opportunity Report, 2010.

[14] J. Spiers, M. Contestabile, Y. Houari, R. Gross, The future of lithium availability for electric vehicle batteries, Renewable and Sustainable Energy Reviews. (2014).

[15] Commodity Markets Outlook, World Bank Group, 2016.

[16] C. Helman, All This Battery Hype Should Make Tesla Investors Nervous, Forbes. (2015). http://www.forbes.com/sites/christopherhelman/2015/05/12/all-this-batteryhype-should-make-tesla-investors-nervous/ (accessed January 26, 2016).

[17] H. Lee, Volkswagen Scandal Boosts Battery Outlook for Seoul Star LG Chem, Bloomberg. (2015). http://www.bloomberg.com/news/articles/2015-10-28/volkswagenscandal-boosts-battery-outlook-for-seoul-star-lg-chem (accessed January 26, 2016).

[18] M. Saito, R. Murai, Driving profits: Panasonic to expand in lithium-ion batteries, 
Reuters. (2013). http://www.reuters.com/article/panasonic-autos-batteriesidUSL4N0GM1ZB20130821 (accessed January 26, 2016).

[19] Annual Report 2015: Panasonic Corporation, Panasonic, n.d. http://www.panasonic.com/global/corporate/ir/pdf/panasonic_ar2015_e.pdf. 